\title{
Evaluating the periphyton as a bioreactor for removal of nutrients in a shallow hypereutrophic reservoir
}

\author{
Avaliando o perifíton como biorreator para remoção de nutrientes em um reservatório \\ raso hipereutrófico
}

\section{Suele Aparecida Mendes-Santos ${ }^{1}$ (D) and Carla Ferragut ${ }^{1^{*}}$ (D)}

\author{
${ }^{1}$ Núcleo de Pesquisa em Ecologia, Instituto de Botânica, Av. Miguel Stéfano, 3687, CEP 04301-902, \\ São Paulo, SP, Brasil \\ *e-mail: cferragut@ibot.sp.gov.br
}

Cite as: Mendes-Santos, S. A. and Ferragut, C. Evaluating the periphyton as a bioreactor for removal of nutrients in a shallow hypereutrophic reservoir. Acta Limnologica Brasiliensia, 2021, vol. 33, e10.

\begin{abstract}
Aim: We evaluated the periphyton on artificial substrate in the treated sewage effluent, effluent patch, inside and after the macrophyte stand in a shallow hypereutrophic reservoir. Specifically, we investigated the relationship between $\mathrm{N}$ and $\mathrm{P}$ contents and algal biomass in the periphyton with $\mathrm{N}$ and $\mathrm{P}$ availability, focusing on nutrient retention. Methods: Periphyton sampling was performed at the effluent inlet, effluent path, inside, and two sites after macrophyte stand. Periphyton sampling was performed after 30 days of colonization. Abiotic variables were determined in the sewage effluent and in the reservoir water. Results: Biomass and N and P contents in the periphyton were significantly different among sampling sites. The highest nutrient concentrations were found in the sampling sites with effluent. The highest periphyton chlorophyll-a were found inside and after the macrophyte stand, while $\mathrm{N}$ and $\mathrm{P}$ contents were the highest in the effluent inlet and effluent. Conclusions: In conclusion, $\mathrm{N}$ and $\mathrm{P}$ contents in the periphyton were associated with $\mathrm{N}$ and $\mathrm{P}$ availability, evidencing the ability of nutrient retention of the community. Our findings suggest that periphyton on artificial substrate can as a potential tool for removing $\mathrm{N}$ and P from the effluent from the sewage treatment system, contributing to minimizing the nutrient load discharged in a shallow reservoir.
\end{abstract}

Keywords: biomass; biofilm; nutrient removal; nutrient content; secondary sewage treatment.

Resumo: Objetivos: Avaliamos o perifíton em substrato artificial no efluente de esgoto tratado, no percurso do efluente, dentro e após o banco de macrófitas em um reservatório raso hipereutrófico. Especificamente, investigamos a relação entre os conteúdos de $\mathrm{N}$ e $\mathrm{P}$ e a biomassa de algas no perifíton com a disponibilidade de $\mathrm{N}$ e $\mathrm{P}$ do ambiente, com foco na retenção de nutrientes. Métodos: A amostragem do perifíton foi realizada no efluente e ao longo do percurso do efluente, dentro e em dois locais após o banco de macrófitas. A amostragem do perifíton foi realizada após 30 dias da colonização. As variáveis abióticas foram determinadas no efluente do esgoto e na água do reservatório. Resultados: Os valores de biomassa e conteúdo N e P no perifíton foram significativamente diferentes entre os locais de amostragem. As maiores concentraçóes de nutrientes foram encontradas nos locais com efluente. As maiores concentraçóes de clorofila- $a$ no perifíton foram encontradas dentro e após o banco de macrófitas, enquanto os maiores teores de $\mathrm{N}$ e P foram encontrados no efluente e no percurso do efluente. Conclusóes: Em conclusão, os conteúdos de $\mathrm{N}$ e $\mathrm{P}$ no perifíton foram associados à disponibilidade de $\mathrm{N}$ e $\mathrm{P}$, evidenciando a capacidade de retenção de nutrientes da comunidade. Nossos resultados sugerem que o perifíton em substrato artificial pode ser uma ferramenta para a remoção de $\mathrm{N}$ e P do efluente do sistema 
de tratamento de esgoto, contribuindo para minimizar a carga de nutrientes descarregada em um reservatório raso.

Palavras-chave: biomassa; biofilme; conteúdo de nutrientes; esgoto com tratamento secundário remoçấo de nutrientes.

\section{Introduction}

Eutrophication is a well-documented environmental problem worldwide (Schindler, 2012, Le Moal et al., 2019). The increase in algal biomass, changes in species composition, and structural simplification are some of the effects of eutrophication on biological communities (Wetzel, 2001). In freshwater ecosystems, phosphorus is a necessary macronutrient for primary producers, and it is considered a primary nutrient limiting algal growth. A reduction in phosphorus supply has successfully reduced eutrophication in lakes and reservoirs (Schindler, 2012). Thus, the reduction of phosphorus availability is essential for the restoration of most eutrophic ecosystems. In this context, periphyton can play an important role in the removal of nutrients due ability to assimilate, immobilize, and internally recycle $\mathrm{N}$ and $\mathrm{P}$ efficiently, reducing nutrient supply in the ecosystem (Dodds, 2003; Sutherland \& Craggs, 2017). Different types of technologies using periphyton for the removal of nutrients in wastewater treatments have been successfully tested (Sutherland \& Craggs, 2017; Wu et al., 2018, Gao et al., 2015). Studies reported the potential application of periphyton to minimize non-point nutrient pollution and remove phosphorus from sewage treatment systems (Lu et al., 2014, Cao et al., 2014, Sutherland \& Craggs, 2017). Although the use of periphyton bioreactor to remove nutrients from enriched systems is recognized worldwide, this approach is still little investigated in Brazil (Morashashi et al., 2019).

In the present study, we evaluated the periphyton on artificial substrate in the treated sewage effluent, inside and after the macrophyte stand, investigating the potential of the community as a bioreactor. Specifically, we investigated the relationship between $\mathrm{N}$ and $\mathrm{P}$ contents and algal biomass in the periphyton with $\mathrm{N}$ and $\mathrm{P}$ availability, focusing on nutrient retention. The present study contributes to a better understanding of the use of periphyton as a bioreactor to remove phosphorus in shallow tropical reservoirs.

\section{Material and Methods}

\subsection{Study area}

The Garças Reservoir is located in the Fontes do Ipiranga State Park (2338’40.6 “S, 46 37’28.0” W), which is located São Paulo, Brazil (Figure 1). It is a shallow urban reservoir $\left(Z_{\max }=4.7 \mathrm{~m}\right.$; $\mathrm{Zmed}=2.1 \mathrm{~m})$ and classified as hypereutrophic (Bicudo et al., 2020). The reservoir has a surface area of $88,156 \mathrm{~m}^{2}$, a volume of $188,785 \mathrm{~m}^{3}$, and a mean theoretical residence time of 71 days. The climate is classified as high altitude tropical with rainy summers and dry winters. About 20 years ago, the macrophyte coverage reached $40-70 \%$ of the water surface causing mosquitoes' proliferation (Bicudo et al., 2007). To mitigate this problem, macrophytes were removed mechanically and management actions were initiated (Bicudo et al., 2020). Currently, macrophytes are trapped by a structure made of bamboo and metal mesh. Despite the discharge of untreated domestic sewage had been interrupted, the secondary treatment effluent is still discharged into the ecosystem. The effluent from the secondary sewage treatment is discharged at a point in the riparian forest, then it percolates into the macrophyte stand in the littoral zone of the reservoir. This effluent is secondary wastewater treatment plant in the city zoo. During the experimental period (09/11/2016 to 09/12/2016), the air temperature ranged from 14.7 to $23.8^{\circ} \mathrm{C}$ and daily rainfall varied from 0 to $40 \mathrm{~mm}$ (Instituto de Astronomia, Geofísica e Ciências Atmosféricas IAG/USP, 2019).

\subsection{Sampling design}

In the littoral zone, effluent or water and periphyton sampling were performed at the effluent inlet, effluent path, inside, and after macrophyte stand (replication: $\mathrm{n}=3$ ), totaling 15 sampling sites. In the forest, a pipe discharges the secondary sewage treatment effluent, forming a place of the accumulation, which is called the effluent inlet. In this place, the effluent overflows and runs about $10 \mathrm{~m}$ until it enters the macrophyte stand (Eichhornia crassipes Mart. (Solms); Eichhornia azurea $(\mathrm{Sw})$ Kunth); this path was called the effluent path. The sampling sites were designated as: EI, effluent inlet; EP, effluent path (10-15 m away from the source); M, macrophyte stand (Eichhornia crassipes; 20-30 m away from the source); AS, $1 \mathrm{~m}$ after stand ( $40 \mathrm{~m}$ away from the source); AM, $10-15 \mathrm{~m}$ away from the macrophyte stand $(50 \mathrm{~m}$ 
A

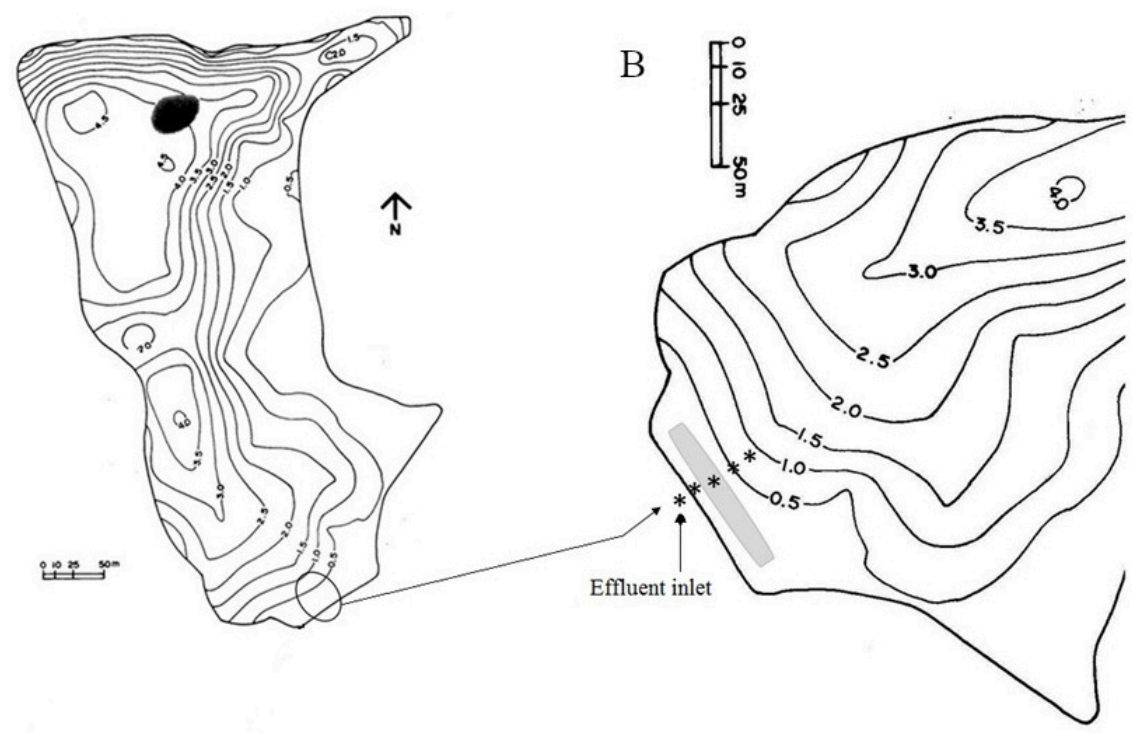

Figure 1. A. The location of the sampling area in the Garças Reservoir bathymetric map (B; Bicudo et al., 2002). B. Scheme showing the sequence of the sampling sites from the discharge of the effluent (effluent inlet; effluent path; inside macrophyte stand; after $1 \mathrm{~m}$ from the macrophyte stand; $10-15 \mathrm{~m}$ away from the stand). The gray area represents the macrophyte stand.

away from the source). The water column depth varied from 20 to 50 centimeters at the first four sampling sites and was 1.5 meters at the last one.

Fifteen acrylic supports with ten glass slides for periphyton colonization each were submerged at a depth of $15 \mathrm{~cm}$ in the sampling sites. After 30 days of exposure, the colonized substrates were collected. In the macrophyte stand, the artificial substrates were placed near Eichhornia crassipes, aiming at a better representation of the epiphyton. The periphyton on artificial substrates was removed by scraping and jets of distilled water. The artificial substrate was chosen to exclude the influence of macrophyte on periphyton nutrient status.

\subsection{Environmental variables analyzed}

In the field, underwater radiation was measured using quantometer (Li-Cor LI-250A) and temperature and $\mathrm{pH}$ using underwater multiparameter probe (Horiba U-50, Kyoto, Japan). The concentrations of dissolved oxygen (DO; azide-modification method), free $\mathrm{CO}_{2}$ (calculated from alkalinity and $\mathrm{pH}$ ), nitrate (cadmium reduction method), nitrite (diazotization method), ammonium (phenate method), orthophosphate (ascorbic acid method), total nitrogen (TN) and total phosphorus (TP) (alkaline persulfate method) were determined according to APHA (2005). The nitrite, nitrate and ammonium concentrations were summed to determine dissolved inorganic nitrogen (DIN). The water samples for the dissolved nutrients were filtered through glass-fiber filters (GF/F Whatman, Maidstone, UK).

\subsection{Periphyton}

We determined periphyton chlorophyll-a (corrected for phaeophytin) from a sample filtered on glass-fiber filters (GF/F Whatman, Maidstone, UK), following $24 \mathrm{~h}$ extraction with $90 \%$ ethanol in the dark (Sartory \& Grobbelaar, 1984). We filtered periphyton samples on glass-fiber filters (GF/F Whatman, Maidstone, UK), which were pre-calcined and weighed to determine dry mass (DM) and ash-free dry mass (AFDM). AFDM:Chlorophyll ratio (autotrophic index) was calculated according to APHA (2005).

The periphyton TP content was determined by combusting samples at $550^{\circ} \mathrm{C}$ for $1 \mathrm{~h}$ in a muffle and then leaching the samples in $\mathrm{HCl} 1 \mathrm{~N}$ at $80^{\circ} \mathrm{C}$ for 30 min (Andersen, 1976; Pompêo \& Moschini-Carlos, 2003). Subsequently, the samples were analyzed for soluble reactive phosphorus according to the ascorbic acid method (Strickland \& Parsons, 1965). Periphyton TN content was determined by the micro-Kjeldahl method (Umbreit et al., 1964). N and P contents were expressed per dry mass unit (\%DM).

\subsection{Data analysis}

Principal components analysis (PCA) was applied for the abiotic data. PCA was performed based on covariance matrix with limnological data log-transformed, except pH (PC-ORD 7.0; 
McCune \& Mefford, 2011). Based on eigenvalues from randomizations (Peres-Neto et al., 2005), we determined the dimension of interpretation. Pearson correlation $(r)$ was used to evaluate the relationship between axis 1 scores and environmental variables, as well as the correlation between the periphyton nutrient content and dissolved nutrient concentration $(\alpha=0.05)$. Permutational multivariate analysis of variance (one-way PERMANOVA) was applied to detect whether periphyton on artificial substrates were significantly different among sampling sites. This analysis was performed with logarithmic data, using the Bray-Curtis similarity measure and 9999 permutations (Past 4.02, Hammer et al., 2001).

\section{Results}

\subsection{Environmental variables}

Table 1 summarizes the abiotic variables in the water surrounding periphyton at sampling sites. The highest DO concentrations were detected inside the macrophyte stand and at the sites after the stand $(1 \mathrm{~m}$ and $50 \mathrm{~m})$. The highest TN, TP and conductivity values were found at the effluent inlet and effluent path sites. Similarly, the highest $\mathrm{DIN}$ and $\mathrm{PO}_{4}-\mathrm{P}$ concentrations were found in the effluent inlet and effluent path sites (Figures 2A-B). Light availability was higher after the macrophyte stand (Figure 2c).

PCA summarized $97.2 \%$ of limnological data variability in the two first axes (Figure 3). The sampling sites with sewage effluent were associated with high nutrient and free $\mathrm{CO}_{2}$ concentrations $(r>-0.7)$ on the negative side of axis 1 . In contrast, the sampling sites inside and after the macrophyte stand were correlated with high DO concentration, $\mathrm{pH}$ and temperature ( $r>0.8)$. Axis 1 represented a gradient of nutrient availability from the effluent input.

\subsection{Periphyton}

The highest periphyton chlorophyll- $a$ were found inside macrophyte stand and after the stand, while the highest dry mass was found in the effluent inlet (Figures 4A-B). The lowest values of the periphyton AFDM:Chlorophyll ratios were found inside and after the macrophyte stand (Figure 4C). Environmental conditions of the sampling sites had significant influence on periphyton nutrient contents and biomass (PERMANOVA: $\mathrm{F}=3.85$; $p=0.002$ ).

The highest $\mathrm{N}$ and $\mathrm{P}$ contents in the periphyton were found in the effluent inlet and effluent path (Figures 5A-B). At 50 meters from the effluent inlet, periphyton $\mathrm{P}$ and $\mathrm{N}$ contents increased again. Periphyton $\mathrm{P}$ content was positively correlated with water $\mathrm{PO}_{4}-\mathrm{P}$ concentration (Pearson: $r=0.8$; $p=0.0003)$ and $\mathrm{N}$ content with DIN concentration (Pearson: $r=0.6 ; p=0.04$ ). Regarding the PCA scores, a negative and significant correlation was found between the $\mathrm{P}$ content and the scores for axis 1 (Pearson: $r=-0.81 ; p=0.0002$ ). Negative and significant correlation was also found between $\mathrm{N}$ content and the axis 1 scores (Pearson: $r=-0.54$; $p=0.05)$.

\section{Discussion}

Our findings showed a difference in the dissolved and total nutrient concentrations between sampling

Table 1. Mean and standard deviation of environmental variables in the sampling sites.

\begin{tabular}{|c|c|c|c|c|c|}
\hline & Effluent Inlet & Effluent path & $\begin{array}{l}\text { Macrophyte } \\
\text { stand }\end{array}$ & After stand & $\begin{array}{l}\text { Away from the } \\
\text { stand }\end{array}$ \\
\hline Conductivity $\left(\mu \mathrm{S} \mathrm{cm} \mathrm{cm}^{-1}\right)$ & $279.0 \pm 53.0$ & $428.0 \pm 33.9$ & $296.7 \pm 38.4$ & $280.3 \pm 1.2$ & $286.3 \pm 4.8$ \\
\hline Depth (m) & $0.20 \pm 0.0$ & $0.20 \pm 0.0$ & $0.20 \pm 0.0$ & $0.29 \pm 0.6$ & $0.56 \pm 0.2$ \\
\hline $\mathrm{DO}\left(\mathrm{mg} \mathrm{L}^{-1}\right)$ & $3.3 \pm 0.8$ & $2.3 \pm 0.3$ & $12.1 \pm 2.5$ & $10.7 \pm 1.6$ & $11.6 \pm 2.8$ \\
\hline $\mathrm{NO}_{2}-\mathrm{N}\left(\mu \mathrm{g} \mathrm{L}^{-1}\right)$ & $179.1 \pm 2.6$ & $205.7 \pm 7.1$ & $5.5 \pm 0.6$ & $13.6 \pm 8.7$ & $5.0 \pm 0.0$ \\
\hline $\mathrm{NO}_{3}-\mathrm{N}\left(\mu \mathrm{g} \mathrm{L}^{-1}\right)$ & $30.2 \pm 19.0$ & $18.5 \pm 1.1$ & $6.1 \pm 0.8$ & $14.8 \pm 6.2$ & $5.0 \pm 0.0$ \\
\hline $\mathrm{NH}_{4}-\mathrm{N}\left(\mu \mathrm{g} \mathrm{L}^{-1}\right)$ & $400.3 \pm 9.7$ & $322.3 \pm 10.7$ & $<5.0$ & $7.8 \pm 3.7$ & $<5.0$ \\
\hline $\mathrm{TN}\left(\mu \mathrm{g} \mathrm{L}^{-1}\right)$ & $7764.0 \pm 14.3$ & $7001.4 \pm 166.1$ & $6003.0 \pm 707.4$ & $2677.4 \pm 60.5$ & $2830.8 \pm 496.6$ \\
\hline $\operatorname{TDP}\left(\mu \mathrm{g} \mathrm{L}^{-1}\right)$ & $79.3 \pm 46.6$ & $188.0 \pm 70.2$ & $37.9 \pm 7.9$ & $41.3 \pm 9.4$ & $24.9 \pm 1.7$ \\
\hline $\mathrm{TP}\left(\mu \mathrm{g} \mathrm{L^{-1 } )}\right.$ & $938.5 \pm 170.4$ & $789.5 \pm 70.2$ & $775.9 \pm 299.4$ & $215.0 \pm 28.6$ & $165.1 \pm 60.7$ \\
\hline $\mathrm{PO}_{4}-\mathrm{P}\left(\mu \mathrm{g} \mathrm{L}^{-1}\right)$ & $599.4 \pm 29.5$ & $312.3 \pm 66.0$ & $7.4 \pm 2.0$ & $18.7 \pm 8.0$ & $<4.0$ \\
\hline Light $\left(\mu \mathrm{mol} \mathrm{m} \mathrm{m}^{-2} \mathrm{~s}^{-1}\right)$ & $30.9 \pm 9.4$ & $140.4 \pm 87.8$ & $216.2 \pm 57.7$ & $451.8 \pm 48.2$ & $720.0 \pm 137.9$ \\
\hline \%Light & $56.7 \pm 13.6$ & $56.9 \pm 11.7$ & $33.0 \pm 3.9$ & $76.7 \pm 10.2$ & $79.4 \pm 11.7$ \\
\hline Temperature $\left({ }^{\circ} \mathrm{C}\right)$ & $23.1 \pm 0.5$ & $22.9 \pm 0.1$ & $24.3 \pm 0.3$ & $24.8 \pm 0.1$ & $25.2 \pm 0.3$ \\
\hline $\mathrm{pH}$ & $5.7 \pm 1.6$ & $5.4 \pm 1.0$ & $8.6 \pm 0.8$ & $9.5 \pm 0.1$ & $9.8 \pm 0.1$ \\
\hline $\operatorname{TDS}\left(\mathrm{g} \mathrm{L}^{-1}\right)$ & $0.6 \pm 0.5$ & $0.3 \pm 0.0$ & $0.2 \pm 0.0$ & $0.2 \pm 0.0$ & $0.2 \pm 0.0$ \\
\hline
\end{tabular}



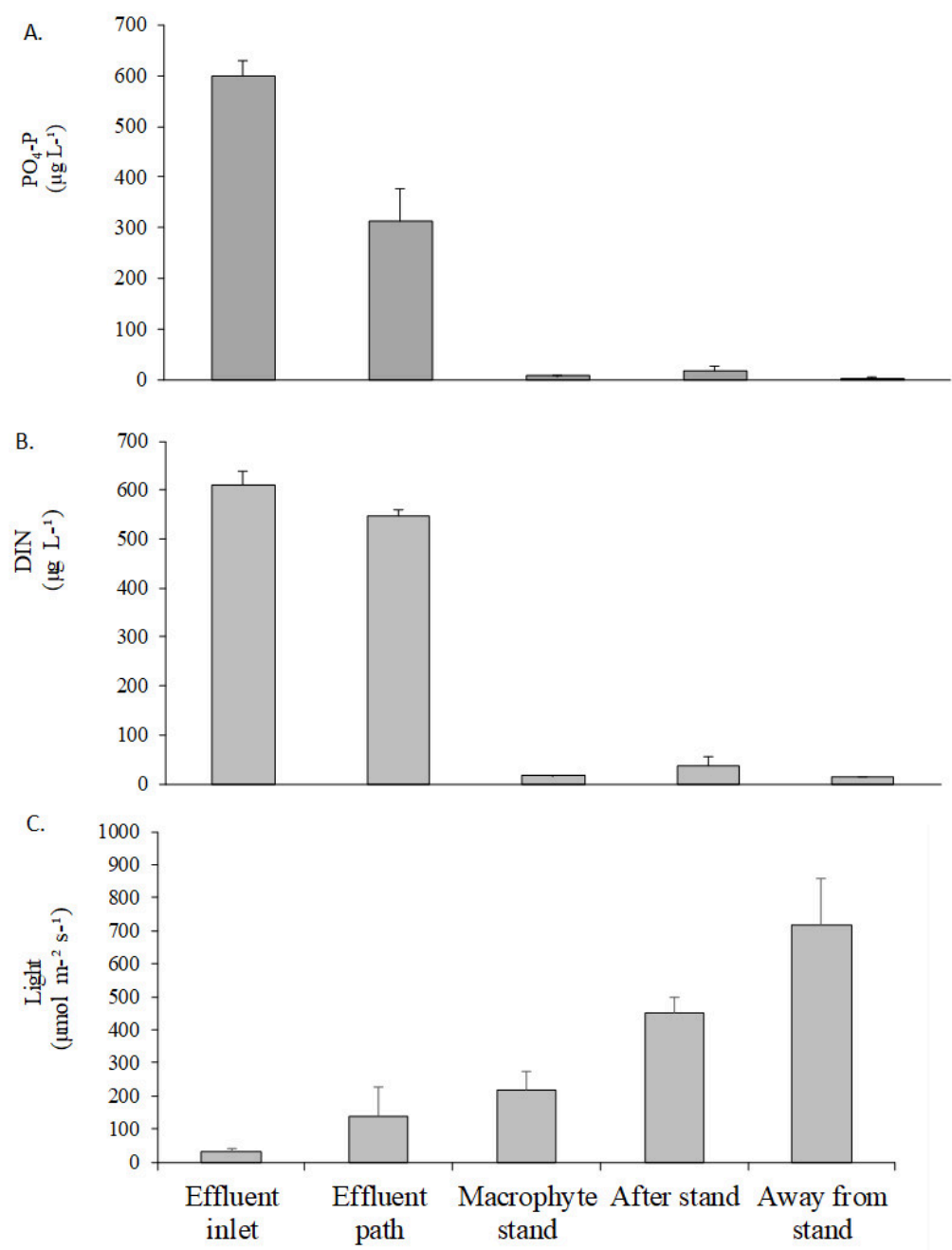

Figure 2. Dissolved nutrient concentrations and light availability (mean; SD; $n=3$ ) in the sampling sites.

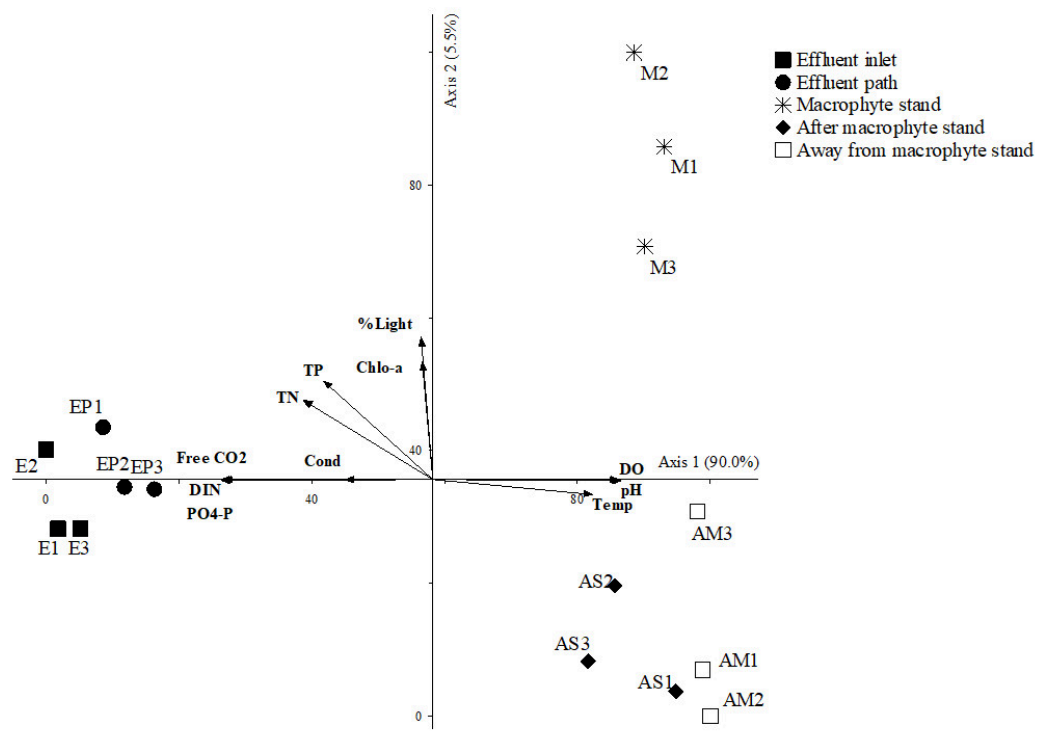

Figure 3. PCA of environmental variables in the sampling sites. Abbreviations: the letters indicate the sampling sites (E, effluent inlet; EP, effluent path; M, inside macrophyte stand; AS, after $1 \mathrm{~m}$ from the macrophyte stand; AM, 10-15m away from the macrophyte stand), and the last number indicates the three replicates $(1,2,3)$ from each sampling site. 

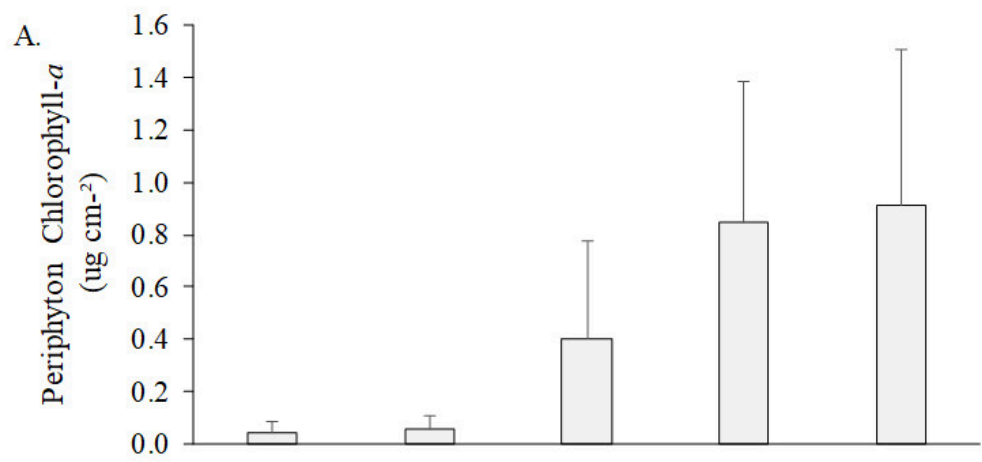

B.

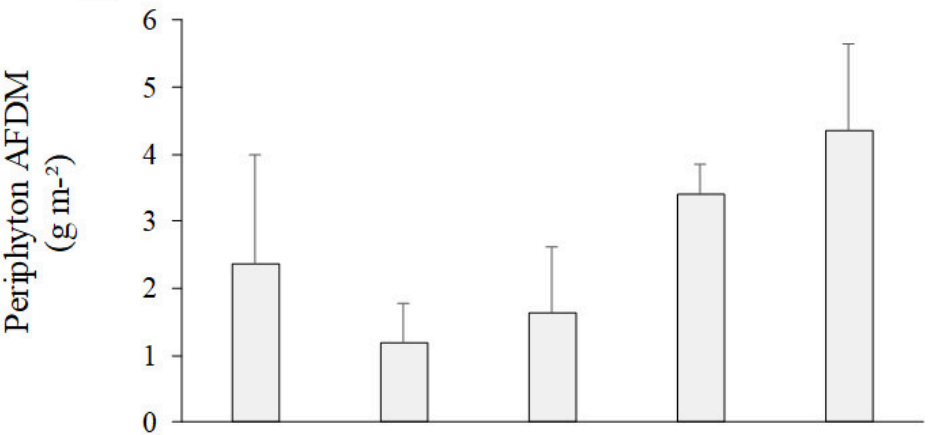

C.

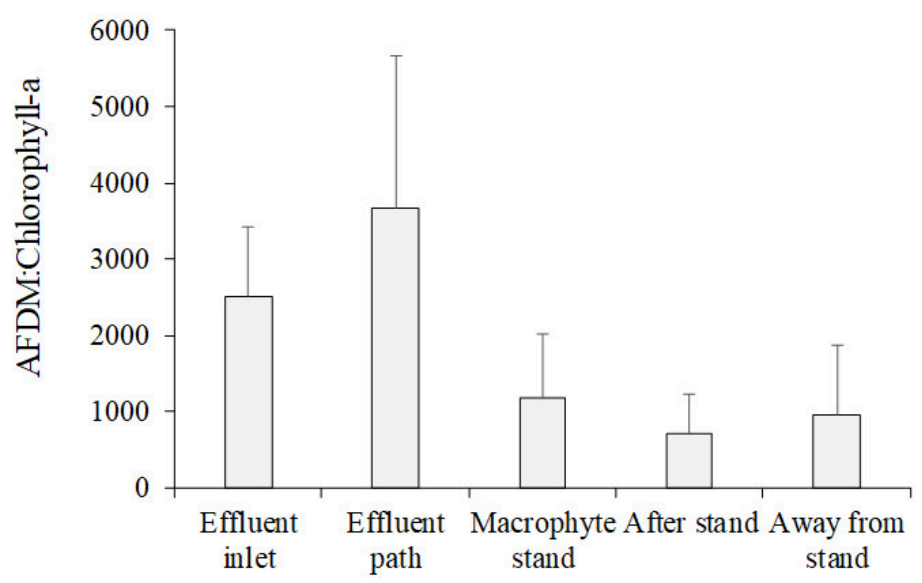

Figure 4. Periphyton chlorophyll- $a$, ash free dry mass (AFDM) and AFDM:Chlorophyll ratio (mean; SD; $\mathrm{n}=3$ ) in the sampling sites.

sites, showing an $\mathrm{N}$ and $\mathrm{P}$ availability gradient from the discharge of effluent from the secondary sewage treatment system. Comparing to long-term studies in the current reservoir (Crossetti et al., 2019; Bicudo et al., 2020), dissolved nutrient concentrations were extremely high in the inlet effluent, demonstrating the high nutrient load that discharged into the reservoir. We observed that total and dissolved nutrient concentrations were substantially reduced inside and after the macrophyte stand (55-76\%) when compared to sampling sites with treated sewage. Several factors may have acted on reducing the nutrient concentration inside and after macrophyte stand, such as dilution and chemical processes (Vymazal,
2007). However, the macrophyte stand that is restricted to an area of the reservoir can function as an artificial wetland, in which Eichhornia crassipes is the dominant species. According to a study in Brazilian tropical constructed wetlands, the removal of TP and TN from effluents averaged $50 \%-80 \%$ efficiency depending on the climatic period (Lautenschlager, 2001; Travaini-Lima \& Sipaúba-Tavares, 2012). The efficiency of E. crassipes in removing nutrients from different systems has been demonstrated (Patel, 2012; Zhang et al., 2019), including sewage treatment systems (Dellarossa et al., 2001; Mishra \& Maiti, 2017). In constructed wetlands, macrophytes and periphyton are considered efficient in removing nutrients from 

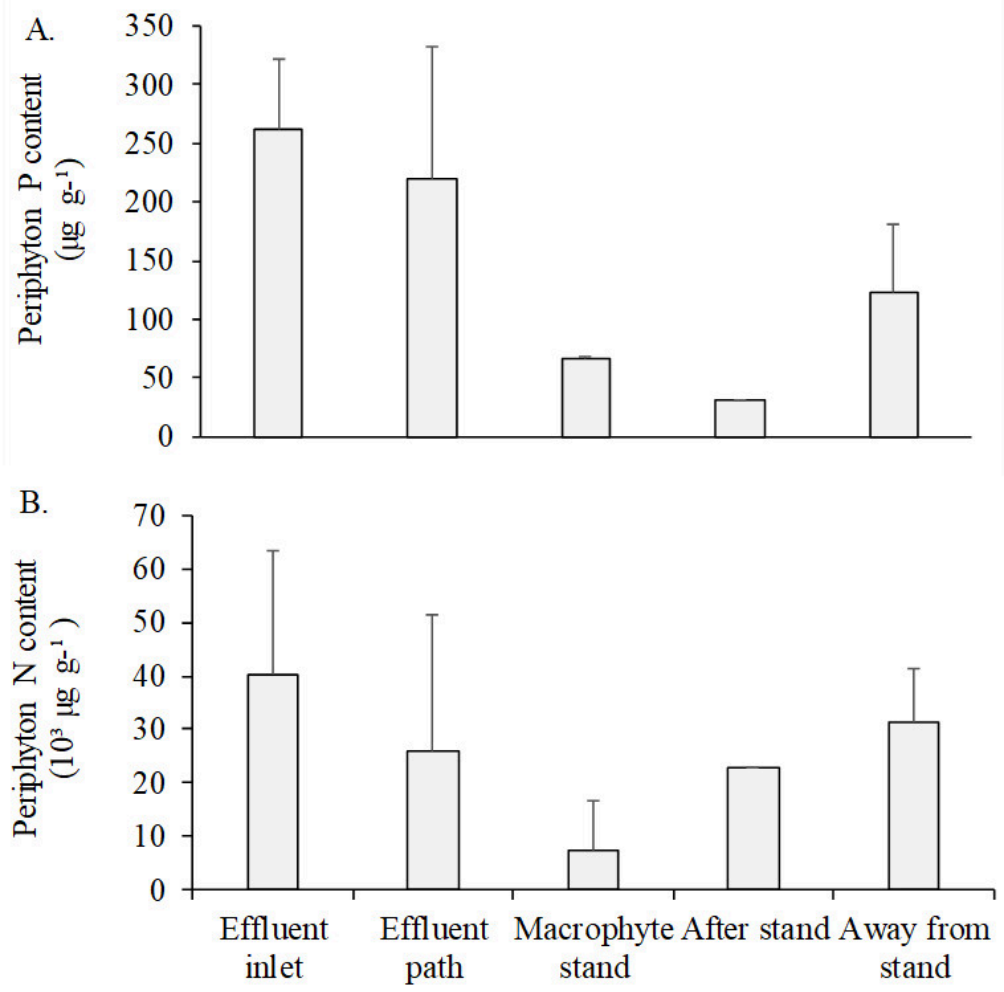

Figure 5. Periphyton $\mathrm{N}$ and $\mathrm{P}$ contents (mean; SD; $\mathrm{n}=3$ ) in the sampling sites.

effluents (Vymazal, 2007; Gu \& Dreschel, 2008; Sutherland \& Craggs, 2017). In the present study, our findings suggested that macrophyte-periphyton complex may have acted in reducing the $\mathrm{N}$ and $\mathrm{P}$ concentration from treated sewage effluent.

We found that the $\mathrm{N}$ and $\mathrm{P}$ contents in the periphyton on artificial substrate were coupled with the nutrient availability of the environment. Thus, the highest periphyton $\mathrm{N}$ and $\mathrm{P}$ contents were found in the treated sewage effluent. In freshwater ecosystems, the relationship between periphyton $\mathrm{P}$ content and water $\mathrm{P}$ concentration has been widely reported in the literature (e.g., Gaiser et al., 2004), including the study area reservoir (Santos et al., 2018). Studies demonstrated the ability of periphyton to remove and retain phosphorus in wastewater with high-load phosphorus (Cao et al., 2014; Lu et al., 2014, Gao et al., 2015). On artificial substrates of different complexities, Wu et al. (2010) demonstrated that the periphyton bioreactor was a promising tool for controlling cyanobacterial growth in Chinese lakes. According to the review study, several technologies have been developed based on the potential of the periphytic algae community to remove wastewater nutrients (Sutherland \& Craggs, 2017). As described in the literature, our results also suggested that periphyton on the artificial substrate can be used to remove nutrients from sewage effluent in the hypereutrophic reservoir studied here.

We found the highest periphyton chlorophyll-a inside and after the macrophyte stand. In these sites, AFDM:Chlorophyll ratio also evidenced greater participation of the autotrophic component in the periphyton. The low light availability may have been a determining factor for the low algal biomass in the periphyton in the inlet and path effluent, where the riparian forest causes strong shading. Despite the low algal biomass in the periphyton, we highlight that algae have functional characteristics that can contribute to the nutrient storage under low light availability, such as mixotrophy. The low light availability can favor the mixotrophic algae growth, which ingests bacteria or particulate matter (Rothhaupt, 1996). A previous study reported a high abundance of mixotrophic algae in the periphyton and phytoplankton (Borduqui et al., 2012; Crossetti et al., 2019; Amaral et al., 2020). For example, Trachelomonas, Ceratium, and Cryptomonas species are common in the plankton and periphyton in the reservoir current. According to the literature, these genera are potentially mixotrophic (Chen et al., 2016; Hansson et al., 2019). Thus, periphyton can present algae with 
adaptive strategies to grow in low light availability, as observed in the treated sewage effluent.

Our findings showed that periphyton can as a tool for removing $\mathrm{N}$ and $\mathrm{P}$ from the effluent from the secondary sewage treatment system. Besides, periphytic algae contributed more to the removal of nutrients inside and after the macrophyte stand, where there was higher light availability. The results suggest that the algal community's contribution to nutrient retention should be greater in non-shaded sites. In conclusion, $\mathrm{N}$ and $\mathrm{P}$ contents in the periphyton were associated with $\mathrm{N}$ and $\mathrm{P}$ availability, evidencing the ability of nutrient retention of community. Our findings suggested that periphyton on artificial substrate can as a potential tool for removing $\mathrm{N}$ and $\mathrm{P}$ from the effluent from the sewage treatment system, contributing to minimizing the nutrient load discharged in a shallow reservoir.

\section{Acknowledgements}

The authors thank the PIBIC - CNPq (Conselho Nacional de Desenvolvimento Científico e Tecnológico) for a fellowship given to SAMS. The authors are grateful to Ms Diego Alberto Tavares for her help in the field. The authors are very grateful to the students and technicians involved in laboratory work.

\section{References}

ANDERSEN, J.M. An ignition method for determination of total phosphorus in lake sediments. Water Research, 1976, 10, 329-331.

AMERICAN PUBLIC HEALTH ASSOCIATION APHA. American Water Works Association. Water Environment Federation. Standard Methods for the Examination of Water and Wastewater. 21st ed. Washington, DC: APHA, 2005.

AMARAL, L.M., CASTILHO, M.C.A., HENRY, R. and FERRAGUT, C. Epipelon, phytoplankton and zooplankton responses to the experimental oligotrophication in a eutrophic shallow reservoir. Environmental Pollution, 2020, 263(Pt A), 114603. http://dx.doi.org/10.1016/j.envpol.2020.114603. PMid:33618459.

BICUDO, C.E.M., CARMO, C.F., BICUDO, D.C., HENRY, R., PIÁO, A.C.S., SANTOS, C.M. and LOPES, M.R.M. Morfologia e morfometria de três reservatórios no PEFI. In D.C. BICUDO, M.C. FORTI and C.E.M. BICUDO, eds. Parque Estadual das Fontes do Ipiranga (PEFI): unidade de conservação que resiste à urbanização de São Paulo. Sáo Paulo: Secretaria do Meio Ambiente do Estado de São Paulo, 2002, pp. 143-160.
BICUDO, D.C., ZANON, J.E., FERRAGUT, C., CROSSETTI, L.O., FAUSTINO, S. and BICUDO, C.E.M. Garças Reservoir trophic state dynamics: a 20-year synthesis. Hoehnea, 2020, 47, e722019. http://dx.doi.org/10.1590/2236-8906$72 / 2019$.

BICUDO, D.C., FONSECA, B.M., BINI, L.M., CROSSETTI, L.O., BICUDO, C.E.M. and ARAÚJO-JESUS, T. Undesirable side-effects of water hyacinth control in a shallow tropical reservoir. Freshwater Biology, 2007, 51(6), 1120-1133. http:// dx.doi.org/10.1111/j.1365-2427.2007.01738.x.

INSTITUTO DE ASTRONOMIA, GEOFÍSICA E CIÊNCIAS ATMOSFÉRICAS - IAG/USP. Boletim climatológico anual da estação meteorológica [online]. São Paulo: IAG/USP, 2016. [viewed 01 Feb. 2019] Available from: http://www.estacao.iag.usp. br/boletim.php.

BORDUQUI, M., FERRAGUT, C. and BICUDO, C.E.M. Factors determining periphytic algae succession in a tropical hypereutrophic reservoir. Hydrobiologia, 2012, 683(1), 109-122. http://dx.doi. org/10.1007/s10750-011-0943-6.

CAO, J., HONG, X. and PEI, G. Removal and retention of phosphorus by periphyton from wastewater with high organic load. Water Science and Technology, 2014, 70(1), 62-69. http://dx.doi.org/10.2166/ wst.2014.195. PMid:25026580.

CHEN, N., LIU, L., QIAO, D., LI, Y. and LV, Y. Seasonal succession patterns of plankton in eutrophic rivers on plains. Annales de Limnologie-International Journal of Limnology, 2016, 52, 217-233. http:// dx.doi.org/10.1051/limn/2016007.

CROSSETTI, L.O., BICUDO, D.C., BINI, L.M., DALA-CORTE, R.B., FERRAGUT, C. and BICUDO, C.E.M. Phytoplankton species interactions and invasion by Ceratium furcoides are influenced by extreme drought and water-hyacinth removal in a shallow tropical reservoir. Hydrobiologia, 2019, 831(1), 71-85. http://dx.doi.org/10.1007/ s10750-018-3607-y.

DELLAROSSA, V., CÉSPEDES, J. and ZAROR, C. Eichhornia crassipes-based tertiary treatment of Kraft pulp mill effluents in Chilean Central Region. Hydrobiologia, 2001, 443(1-3), 187-191. http:// dx.doi.org/10.1023/A:1017507932543.

DODDS, W.K. The role of periphyton in phosphorus retention in shallow freshwater aquatic systems. Journal of Phycology, 2003, 39(5), 840-849. http:// dx.doi.org/10.1046/j.1529-8817.2003.02081.x.

GAISER, E.E., SCINTO, L.J., RICHARDS, J.H., JAYACHANDRAN, K., CHILDERS, D.L., TREXLER, J.C. and JONES, R.D. Phosphorus in periphyton mats provides the best metric for detecting low-level P enrichment in an oligotrophic wetland. Water Research, 2004, 38(3), 507-516. 
http://dx.doi.org/10.1016/j.watres.2003.10.020. PMid:14723918.

GAO, F., YANG, Z.H., LI, C., ZENG, G.M., MA, D.H. and ZHOU, L. A novel algal biofilm membrane photobioreactor for attached microalgae growth and nutrients removal from secondary effluent. Bioresource Technology, 2015, 179, 8-12. http://dx.doi.org/10.1016/j.biortech.2014.11.108. PMid:25514396.

GU, B. and DRESCHEL, T. Effects of plant community and phosphorus loading rate on constructed wetland performance in Florida, USA. Wetlands, 2008, 28(1), 81-91. http://dx.doi.org/10.1672/07-24.1.

HAMMER, Ø., HARPER, D.A.T. and RYAN, P.D. PAST: Paleontological Statistics software package for education and data analysis. Palaeontologia Electronica, 2001, 4(1), 1-9.

HANSSON, T.H., GROSSART, H.P., DEL GIORGIO, P.A., ST-GELAIS, N.F. and BEISNER, B.E. Environmental drivers of mixotrophs in boreal lakes. Limnology and Oceanography, 2019, 64(4), 16881705. http://dx.doi.org/10.1002/lno.11144.

LAUTENSCHLAGER, S.R. Modelagem do desempenho de wetlands construidas [Dissertação de Mestrado]. São Paulo: Escola Politécnica da Universidade de São Paulo, 2001. 106 p. http://dx.doi. org/10.11606/D.3.2001.tde-11072002-091741.

LE MOAL, M., GASCUEL-ODOUX, C., MÉNESGUEN, A., SOUCHON, Y., ÉTRILLARD, C., LEVAIN, A., MOATAR, F., PANNARD, A., SOUCHU, P., LEFEBVRE, A. and PINAY, G. Eutrophication: a new wine in an old bottle? The Science of the Total Environment, 2019, 651(Pt 1), 1-11. http://dx.doi.org/10.1016/j. scitotenv.2018.09.139. PMid:30223216.

LU, H., YANG, L., SHABBIR, S. and WU, Y. The adsorption process during inorganic phosphorus removal by cultured periphyton. Environmental Science and Pollution Research International, 2014, 21(14), 8782-8791. http://dx.doi.org/10.1007/ s11356-014-2813-z. PMid:24728572.

MCCUNE, B. and MEFFORD, M.J. PC-ORD. Multivariate analysis of ecological data. Oregon: $\mathrm{MjM}$ Software Design, 2011.

MISHRA, S. and MAITI, A. The efficiency of Eichhornia crassipes in the removal of organic and inorganic pollutants from wastewater: a review. Environmental Science and Pollution Research International, 2017, 24(9), 7921-7937. http://dx.doi.org/10.1007/ s11356-016-8357-7. PMid:28092006.

MORASHASHI, A.C., JESUS, T.A., ROSA, D.S., HARADA, J. and BICUDO, D.C. Avaliaçấo e comparação do acúmulo de fósforo por biofilme formado sobre lâminas de vidro e de filme polimérico biodegradável (Ecovio modificado). Revista Brasileira de Ciência. Tecnologia e Inovação, 2019, 4(2), 131145.

PATEL, S. Threats, management and envisaged utilizations of aquatic weed Eichhornia crassipes: an overview. Reviews in Environmental Science and Biotechnology, 2012, 11(3), 249-259. http://dx.doi. org/10.1007/s11157-012-9289-4.

PERES-NETO, P.R., JACKSON, D.A. and SOMERS, K.M. How many principal components? Stopping rules for determining the number of non-trivial axes revisited. Computational Statistics \& Data Analysis, 2005, 49(4), 974-997. http://dx.doi.org/10.1016/j. csda.2004.06.015.

POMPÊO, M.L.M. and MOSCHINI-CARLOS, V. Macrófitas aquáticas e perifiton: aspectos ecológicos e metodológicos. São Carlos: Rima/FAPESP, 2003.

ROTHHAUPT, K.O. Utilization of substitutable carbon and phosphorus sources by the mixotrophic chrysophyte Ochromonas sp. Ecology, 1996, 77(3), 706-715. http://dx.doi.org/10.2307/2265495.

SANTOS, S.A.M., SANTOS, T.R., FURTADO, M.S., HENRY, R. and FERRAGUT, C. Periphyton nutrient content, biomass and algal community on artificial substrate: response to experimental nutrient enrichment and the effect of its interruption in a tropical reservoir. Limnology, 2018, 19(2), 209-218. http://dx.doi.org/10.1007/s10201-017-0533-z.

SARTORY, D.P. and GROBBELAAR, J.U. Extraction of chlorophyll a from freshwater phytoplankton for spectrophotometric analysis. Hydrobiologia, 1984, 114(3), 177-187. http://dx.doi.org/10.1007/ BF00031869.

SCHINDLER, D.W. The dilemma of controlling cultural eutrophication of lakes. Proceedings. Biological Sciences, 2012, 279(1746), 4322-4333. http://dx.doi. org/10.1098/rspb.2012.1032. PMid:22915669.

STRICKLAND, J.D.H. and PARSONS, T.R. A manual of seawater analysis. Bulletin - Fisheries Research Board of Canada, 1965, 125, 1-185.

SUTHERLAND, D.L. and CRAGGS, R.J. Utilizing periphytic algae as nutrient removal systems for the treatment of diffuse nutrient pollution in waterways. Algal Research, 2017, 25, 496-506. http://dx.doi. org/10.1016/j.algal.2017.05.023.

TRAVAINI-LIMA, F. and SIPAÚBA-TAVARES, L.H. Efficiency of a constructed wetland for wastewaters treatment. Acta Limnologica Brasiliensia, 2012, 24(3), 255-265. http://dx.doi.org/10.1590/S2179975X2012005000043.

UMBREIT, W.W., BURRIS, R.H. and STAUFFER, J.F. Manometric methods applicable to the study of tissue metabolism. Minneapolis: Burgess Publishing Company, 1964.

ZHANG, Y., LIU, H., YAN, S., WEN, X., QIN, H., WANG, Z. and ZHANG, Z. Phosphorus removal from the hyper-eutrophic Lake Caohai (China) 
with large-scale water hyacinth cultivation. Environmental Science and Pollution Research International, 2019, 26(13), 12975-12984. http://dx.doi.org/10.1007/s11356-019-04469-8. PMid:30895539.

WETZEL, R.G. Limnology. New York: Academic Press, 2001, 1006 p.

WU, Y. ZHANG. S., ZHAO H. and YANG, L. Environmentally benign periphyton bioreactors for controlling cyanobacterial growth. Bioresource Technology, 2010, 101, 9681-9687.

WU, Y., LIU, J. and RENE, E.R. Periphytic biofilms: a promising nutrient utilization regulator in wetlands.
Bioresource Technology, 2018, 248(Pt B), 44-48. http://dx.doi.org/10.1016/j.biortech.2017.07.081. PMid:28756125.

VYMAZAL, J. Removal of nutrients in various types of constructed wetlands. The Science of the Total Environment, 2007, 380(1-3), 48-65. http://dx.doi.org/10.1016/j.scitotenv.2006.09.014. PMid:17078997.

Received: 10 September 2020 Accepted: 28 April 2021

Associate Editor: Gustavo Henrique Gonzaga da Silva. 